Goldschmidt 2021 Abstract

https://doi.org/10.7185/gold2021.7552

\section{New FTIR data from the Gutai Mts. and post eruption effects on the hydroxyl content of phenocrysts focused on the Firiza-basalts.}

\author{
ÁKOS KöVÁGÓ ${ }^{1}$, MARINEL KOVACS ${ }^{2}$, DÓRA KESJÁR ${ }^{3}$, \\ CSABA SZABÓ ${ }^{4}$ AND ISTVÁN JÁNOS KOVÁCS ${ }^{5}$ \\ ${ }^{1}$ Magyar Bányászati és Földtani Szolgálat \\ ${ }^{2}$ Technical of University Cluj-Napoca, North University Centre \\ Baia Mare, Baia Mare, Romania \\ ${ }^{3}$ Eötvös Loránd Research Network, Research Centre for \\ Astronomy and Earth Sciences, Institute for Geological and \\ Geochemical Research \\ ${ }^{4}$ Eötvös University \\ ${ }^{5}$ MTA EK Lendület Pannon LitH2Oscope Research Group, \\ Centre for Energy Research \\ Presenting Author: kovago.akos@gmail.com
}

We studied calc-alkaline volcanic rocks from the Oas-Gutai Mts. The major goal of our research was the determination of 'water' content in the phenocrysts of the nominally anhydrous minerals (NAMs) and also to uncover the possible post eruptive changes [1],[4], in the structural hydroxyl content of NAMs. The selected volcanic rocks were studied by petrography, EMPA, LA-ICP-MS, ICP-OES, ICP-MS and FTIR.

Our assumption is that by studying the FTIR spectra of clinopyroxenes [5] enables to estimate original 'water' contents since clinopyroxene is resistant to weathering and the diffusion of structural hydroxyl $\left(\mathrm{H}^{+}\right)$is slower in clinopyroxenes than in other phenocrysts [2],[3].

We found that the clinopyroxenes from the Firiza calc-alkaline basalt likely retained their original 'water' content therefore we could make calculations regarding the magmatic water content in their source region.

\section{$\underline{\text { References: }}$}

[1] Biró, T., Kovács, I., Karátson, D., Stalder, R., Király, E., Falus, G., Fancsik, T., Sándorné Kovács, J. 2017: Evidence for post-depositional diffusional loss of hydrogen in quartz phenocryst fragments within ignimbrites - American Mineralogist, 102(6), 1187-1201

[2] Farver, J.R. 2010: Oxygen and Hydrogen Diffusion in Minerals. Reviews in Mineralogy and Geochemistry, 72(1), 447 507.

[3] Johnson, E. A.; Rossman, G. R. 2013: The diffusion behavior of hydrogen in plagioclase feldspar at $800-1000{ }^{\circ} \mathrm{C}$ : Implications for re-equilibration of hydroxyl in volcanic phenocrysts American Mineralogist 98(10), 1779-1787.

[4] Pálos, Z., Kovács, I. J., Karátson, D., Biró, T., Sándorné Kovács, J., Bertalan, É., Wesztergom, V. 2019: On the use of nominally anhydrous minerals as phenocrysts in volcanic rocks: A review including a case study from the Carpathian-Pannonian Region. Central European Geology, 62(1), 119-152

[5] Patkó, L., Liptai, N., Kovács, I., Aradi, L., Xia, Q.K., Ingrin, J., Mihály, J., O'Reilly, S.Y., GriffiVn, W.L., Wesztergom, V., Szabó, C. 2019: Extremely low structural hydroxyl contents in upper mantle xenoliths from the NógrádGömör Volcanic Field (northern Pannonian Basin): Geodynamic implications and the role of post-eruptive re-equilibration. Chemical Geology, 507, 23-41. 